\title{
Elementary School Mathematics Teacher Trainees' Metacognitive Awareness Levels: Turkey Case
}

Dilek Sezgin Memnun, Ph.D., Uludag University, Turkey

Lynn Cecilia Hart, Ph.D., Georgia State University, USA

\begin{abstract}
The aim of this research is to determine the metacognitive awareness levels of elementary mathematics teacher trainees and to investigate whether their awareness differs according to gender and class level. We also investigate the relationship between the metacognitive awareness levels of trainee mathematics teacher's and their overall performance course grades. The Metacognitive Awareness Inventory, developed by Schraw and Dennison (1994) and adapted into Turkish by Akın, Abacı and Çetin (2007), was implemented with a total of 153 mathematics teacher trainees. Analysis of the data collected suggests that most of the mathematics teacher trainees have a high level of metacognitive awareness. There was no significant difference between the metacognitive awareness levels of mathematics teacher trainees by gender or by class levels. There was a low level, positive relationship between their metacognitive awareness levels and their overall performance on university course grades.
\end{abstract}

Keywords: Metacognition; Metacognitive Awareness; Knowledge of Cognition; Regulation of Cognition; Mathematics Teacher Trainees

\section{INTRODUCTION}

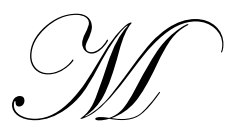

etacognition is a critical ability that affects the problem solving behaviour of individuals and their learning processes (Artzt \& Armour-Thomas, 1992; Fitzpatrick, 1994; Kuiper, 2002; Swanson, 1990). Metacognition includes the efforts of students to understand a problem during problem solving, their thinking during the problem solving process, and their awareness of their thinking processes in relation to their decision making and its regulation (Brown, 1987). Besides this, metacognition plays a principal role in selfregulation, which is a requirement for successful learning (Lucangeli \& Cornoldi, 1997). Kuiper (2002) states that learners who have a good level of self-regulation and metacognitive strategies obtain better academic success. Schraw and Graham (1997) suggest that metacognition is an important element of effective learning since it allows individuals to observe their own performances and to regulate it. Further, they suggest that higher metacognitive performance increases the ability to learn by providing better use of the attention span and more effective use of the strategies that are available.

The term metacognition was put forward by Flavell for the first time in 1976 (Alc1 \& Altun, 2007; Yurdakul, 2005). Flavell (1976: 232) defined metacognition as "knowledge about the cognitive phenomenon and the metacognition" and as "knowledge of the person about self cognition process and the use of this knowledge for controlling of the cognition processes". According to Flavell (1979), metacognition is awareness by an individual of how he/she learns and what he/she does, ability of using cognitive skills required by an ordinary test, the evaluation of individual processes during the performance and after it. Metacognition is the activity or the knowledge which regulates cognitive functions (Flavell, 1993).

After Flavell, metacognition was examined by many researchers and although it has been generally expressed as thinking about cognition (Akın, Abacı \& Çetin, 2007; Blakey \& Spence, 1990; Livingston, 1997), 
different definitions have been put forth. Swanson (1990) suggested that metacognition is the knowledge of the individual about his/her own cognitive processes and the controlling of these processes. Williamson (1996) defined metacognition as the understanding of the individual about his/her own cognitive processes and the ability to control them. Kuiper (2002) defined metacognition as self-communication of the individual with regard to the requirements of the cognitive activity and the requirements of the task before, during and after the task. According to him, metacognition includes thinking about the process and making changes in how we think during the process. In short, metacognition is when the individual is aware of his/her own knowledge, has the ability to control this knowledge within the problem-solving process and is able to self-regulate his/her decision (Alc1 \& Altun, 2007).

Although there are many definitions of metacognition, many researchers (Brown, 1987; Pintrich, 2002; Schraw \& Dennison, 1994; Schraw \& Moshman, 1995) accept the knowledge of cognition and the regulation of cognition as the essential elements/components of metacognition. Knowledge of cognition means how much learners learn through their own learning strategies (Sperling, Howard, Staley \& DuBois, 2004) and what they know about their cognition (Akın, Abacı and Çetin, 2007). Metacognition is knowledge which is formed by the interaction of the variability person, duty and strategy. It stores by the individual, who has different cognitive objectives and abilities and who had different cognitive experience (Flavell, 1979; Flavell, 1993; Livingston, 1997). Knowledge of cognition is divided into three components: declarative knowledge, procedural knowledge and conditional knowledge (Artzt \& Armour-Thomas, 1992). Regulation of cognition contains what is learned as well as the strategies or abilities which encourage learning and provide for reaching the objectives (Flavell, 1979). Although many regulating abilities are defined in the literature (Artzt \& Armour-Thomas, 1992; Blakey \& Spence, 1990; Deseote, Roeyers \& Buysse, 2001; Filho \& Yuzawa, 2001; Jacobs \& Paris, 1987; O'neil \& Abedi, 1996; Pintrich, 1991; Schraw \& Moshman, 1995; Schraw, 1998; Zimmerman \& Martinez-Ponsa, 1989), four principal abilities are mentioned in general. These are; planning, monitoring, regulating and evaluation.

\section{Objective of the Research and Its Importance}

Metacognitive ability makes learning easier by providing the learner with awareness of effective ways for his/her learning and by controlling and monitoring his/her learning (Schraw \& Graham, 1997). Students, who are aware of their metacognitive abilities and cognitive abilities, are more strategic problem solvers; they are aware of their performance and therefore demonstrate better performance. They have more self-confidence when compared to other students who are not as metacognitive (Swanson, 1990). These individuals start to reflect sooner and more quickly when there is a mistake during the execution of a problem and through this process they develop and increase their learning strategies, accept themselves as learners and thinkers, and can therefore cope with new situations (Öz, 2005). Individuals who solve problems in a planned and orderly way and have knowledge about their cognitive processes are more successful at problem solving (Schraw \& Dennison, 1994). In a sense, metacognition has an important place in the education of children and adults alike (Kapa, 2001; Kramarski, Mevarech \& Arami, 2002; Mevarech, 1999; Schoenfeld, 1985; Teong, 2002; Victor, 2004).

Recent research on gender differences and metacognitive activity found no significant differences between male and female teacher trainees (Özsoy \& Günindi, 2011; Tüysüz, Karakuyu \& Bilgin, 2008). Özsoy and Günindi (2011) did find differences in metacognitive awareness by class level (years in school). This was reported previously in the research of Tüysüz, Karakuyu and Bilgin (2008) who found that the metacognitive awareness of teacher trainees increased as the class level increased.

According to some researchers, the metacognition knowledge and awareness affect the success positively (Cardelle-Elawar, 1992; Özcan, 2000; O'neil \& Abedi, 1996). When individuals participate in metacognitive activities such as self-evaluation, monitoring, and readjustment, their learning increases (Lin, 2001). The education that based on metacognition leads to increase in the learning (Schraw \& Graham, 1997). Also having information about cognitive processes, about the features that these processes possess, about their structure, and about their possibilities raises the awareness level about how all of these could be used by the individual in the most effective and the most productive way (Livingston, 1997). This suggests that it is important for teachers and trainee teachers to have high levels of metacognitive awareness. It is important also for teachers to model their own metacognitive processes to enhance their own learning but also to help in the education of their students (Marshall, 2003). Teachers should model for their students both their cognitive and metacognitive activity, whereby increasing the likelihood of 
students developing their own cognitive and metacognitive abilities as much as possible (Butler \& Winne, 1995; Thomas \& McRobbie, 2001). Teachers could both direct students' attention towards this field and provide them to recognise the importance of the metacognitive abilities by providing their lives to students (Thomas \& McRobbie, 2001). For this reason, the determination and development of the metacognitive awareness of teacher trainees that particularly bring up the future generations has a different significance. Teachers should carry out the applications through their metacognitive awareness, compare, analyse and evaluate these applications with the ideal applications and search for the alternatives (Ekiz \& Yiğit, 2007). Because of that, it is important that teacher trainees, who will educate the future generations and therefore shape the future, should be mindful of their own metacognitive and cognitive activity. Metacognitive ability and awareness are important and affect problem solving behaviour and processes, and while much research was found in the literature on metacognition and mathematical problem solving (Artzt \& Armour-Thomas, 1992; Deseoete, Roeyers \& Buysee, 2001; Fitzpatrick, 1994; Kramarski, Mevarech \& Arami, 2001; Swanson, 1990; Teong, 2002 etc.), no research was found on the awareness of the role of metacognition with elementary mathematics teacher trainees, making it a critical area of need.

Given that metacognitive awareness and activity of teacher trainees could affect their individual success and performance as well as have an impact on their students, it is important to assess metacognitive awareness of teacher trainees and to examine what, if any, differences exist along gender or level of schooling. In addition we are interested in finding out if there is a relationship between the metacognitive awareness of teacher trainees and their university grade point average. Therefore we raise the following research questions:

1. What are the metacognitive awareness levels of mathematics teacher trainees?

2. Do metacognitive awareness levels of mathematics teacher trainees show significant differences according to gender?

3. Do metacognitive awareness levels of mathematics teacher trainees show significant difference according to class levels?

4. Is there any relationship between the metacognitive awareness levels of mathematics teacher trainees and levels related to the components of the metacognitive awareness levels (knowledge of cognition and regulation of cognition) and their grade point averages?

\section{METHODOLOGY}

\section{Participants}

A total of 153 teacher trainees, who were studying in the Department of Elementary School Mathematics Teachers of the Education Faculty of Uludag University in Turkey during the 2011-2012 academic year, including 44 freshmen, 45 sophomores, 33 juniors and 30 seniors participated in the research. Eleven of the freshmen teacher trainees, 8 of the sophomores, 11 of the juniors and 12 of the seniors were males.

\section{Data Collection Instrument}

Data for the research was obtained using the Metacognitive Awareness Inventory (MAI), which was developed by Schraw and Dennison (1994) and was transcribed into Turkish by Akın, Abaci and Çetin (2007).. The Metacognitive Awareness Inventory is a 52-item inventory which uses a 5-point Likert scale. The original form of the MAI has eight sub-scales, which are included under the two main scales. The main two scales are: knowledge of cognition and regulation of cognition. The knowledge of cognition scale has three sub-scales: declarative knowledge, procedural knowledge and conditional knowledge. The regulation of cognition scale has five sub-scales: planning, information management, debugging strategies, monitoring and evaluation of learning (Schraw \& Dennison, 1994). The factor loading of the 52 articles contained within the inventory has a range of 0.32 to 0.70 . The internal consistency reliability coefficients have been found to be 0.95 for the whole of the inventory and they have been calculated as 0.88 and 0.93 for the two main scales (Akın, Abacı \& Çetin, 2007).

The structure and consistency validity of the MAI was examined for its Turkish form. After the Turkish version of the MAI that was transcribed into Turkish was given to the teacher trainees, a different Metacognitive Awareness Inventory, which is developed by Yurdakul (2004), was also given to these teacher trainees, for the 
consistence validity. The correlation between these two applications was determined as the consistence validity and the correlation result has been calculated as 0.95 . Exploratory factor analysis has been applied in order to study the structure validity of the inventory and the presence of eight sub-components that are included under the knowledge of cognition and regulation of cognition main components of the original form of the inventory. Test specimen/substance correlation and the lower-upper group comparison with $27 \%$ have been included for substance separation of the MAI The Pearson product-moment correlation coefficient has been determined according to total points of the correlation coefficient for the calculation of the test specimen/substance correlation and the $t$ test was used for the comparison of the substance points of the lower-upper group with $27 \%$. The internal consistency and test-retest reliability coefficients have been calculated for reliability studies of the MAI. The internal consistency reliability coefficient of the inventory has been determined as 0.95 and the internal consistency coefficient of the inventory has been determined as 0.93 (Akın, Abacı \& Çetin, 2007).

Written as a 5-point Likert scale, the highest point value that could be obtained for this inventory is 260 and the lowest point is 52. Higher scores on the MAI, which does not contain negative points, show high level of metacognitive awareness. This awareness level of the individuals can be found by dividing the total points obtained from the inventory to the number of the substances. It can be said that the teacher trainees, who have obtained points lower than 1.25, has very low metacognitive awareness level and the trainees, who has points between 1.25 and 2.49, has low metacognitive awareness level. The teacher trainees, who have points between 2.50-3.74, has high metacognitive awareness level and the trainees, who has points over 3.75 , has very high metacognitive awareness level.

\section{Data Collection and Analysis}

The mathematics teacher trainees were given a total of 30 minutes to complete the MAI. The data were analysed using the SPSS 17.0 program. At this time, descriptive statistics methods were used to determine the metacognitive awareness levels and grade point averages of the teacher trainees. Two sample t-test dependent on frequency distribution related to two or more variables was applied for the analysis of data related to the first research question, a one-way ANOVA with frequency distribution was used for analysis of data related to the second research question, and correlation analysis with frequency distribution was applied for the analysis of data related to the third research question. For all of the statistical decoding, .05 significance level was taken as the base. Cronbach Alpha coefficient related to the inventory was calculated as 0.95 for the data that was obtained from this research.

\section{FINDINGS}

In this section, we report the results of the statistical analysis that was performed to determine the metacognitive awareness levels of the elementary school mathematics teacher trainees. In addition we report the results of whether gender and class levels have any effect on awareness. Finally, we report results of the relationship between the metacognitive awareness levels and the awareness scales (knowledge of cognition and regulation of cognition) and between the metacognitive awareness levels and general success as indicated by class grades of teacher trainees.

Results from the 153 participants were first grouped as very high (range 3.75-5.00), high (2.50-3.74), low (1.25-2.49) and very low (0-1.24). The 38 teacher trainees (24.8\%) have a very high level, 109 teacher trainees (71.2\%) have a high level and 6 teacher trainees (4\%) have low level of metacognitive awareness levels. No teachers were identified as having a very low level. In this case, the majority of the teacher trainees (96\%) have high or very high levels of metacognitive awareness. However, the percentage of teacher trainees with very high level of metacognitive awareness (24.8\%) is rather low when compared to the percentage of the teacher trainees with high level of metacognitive awareness (71.2\%). The four distribution levels of the metacognitive awareness of mathematics teacher trainees and the distribution according to gender are included in Table 1. 
Table 1. Distribution of the Metacognitive awareness Levels of Mathematics Teacher Trainees According to the Gender

\begin{tabular}{|c|c|c|c|c|c|c|}
\hline \multirow{3}{*}{$\begin{array}{l}\text { Metacognitive } \\
\text { Awareness }\end{array}$} & \multicolumn{6}{|c|}{ Gender } \\
\hline & \multicolumn{2}{|c|}{ Female } & \multicolumn{2}{|c|}{ Male } & \multicolumn{2}{|c|}{ Total } \\
\hline & $\mathbf{f}$ & $\%$ & $\mathbf{f}$ & $\%$ & $\mathbf{f}$ & $\%$ \\
\hline Very High & 27 & 24.3 & 11 & 26.2 & 38 & 24.8 \\
\hline High & 82 & 73.9 & 27 & 64.3 & 109 & 71.2 \\
\hline Low & 2 & 1.8 & 4 & 9.5 & 6 & 4.0 \\
\hline Very Low & 0 & 0.0 & 0 & 0.0 & 0 & 0.0 \\
\hline Total & 111 & 100 & 42 & 100 & 153 & 100 \\
\hline
\end{tabular}

Results from the MAI with regard to gender are found in Table 2 . While only $1.8 \%$ of the female teacher trainees have a low level of metacognitive awareness, 9.5\% of the male teacher trainees have a low level of metacognitive awareness. However, the female students in the very high $(24.3 \%)$ and high (73.9\%) range and male students in the very high $(26.2 \%)$ and high $(64.3 \%)$ are rather close to each other. In order to test the differences between the gender of the mathematics teacher trainees and the level of metacognitive awareness, a t-test was applied for independent groups and the results of this test are included in Table 2.

Table 2. Results of the Independent Samples t-Test In Relation to Differentiation of Metacognitive Awareness Levels According to the Gender

\begin{tabular}{lcccccc}
\hline \multicolumn{1}{c}{ Gender } & $\mathbf{N}$ & $\bar{x}$ & $\mathbf{S}$ & $\mathbf{s d}$ & $\mathbf{t}$ & \\
\hline Female & 111 & 3.23 & 0.46 & \multirow{2}{*}{126} & \multirow{2}{*}{1.596} & \multirow{2}{*}{113} \\
Male & 42 & 3.17 & 0.58 & & \\
\hline
\end{tabular}

From Table 2, it was determined that there is not a significant difference between the metacognitive awareness levels of female and male mathematics teacher trainees who participated in this research $\left(\mathrm{t}_{(153)}=1.596\right.$; $\mathrm{p}>.05)$. The average of the metacognitive awareness score of the male teacher trainees $(\bar{x}=3.23)$ and the average of the metacognitive awareness score of the female teacher trainees $(\bar{x}=3.17)$ are at a similar level. Teacher trainees in both of the groups show homogeneous distribution with regard to standard deviation values.

A one-way ANOVA test was used to test whether there is a significant difference between metacognitive awareness levels of the mathematics teacher trainees with respect to class level. The results are found in Table 3 .

Table 3. Results of One-way ANOVA Test in Relation to Variation of the Metacognitive awareness Levels of Mathematics Teacher Trainees According to Their Class Levels

\begin{tabular}{|c|c|c|c|c|c|c|}
\hline & Sum of Squares & sd & $\begin{array}{c}\text { Average of } \\
\text { Squares }\end{array}$ & $\mathbf{F}$ & $\mathbf{p}$ & $\begin{array}{l}\text { Significant } \\
\text { Difference }\end{array}$ \\
\hline Inter-Groups & 1.381 & 3 & .460 & & & \\
\hline Within Groups & 35.926 & 149 & .241 & 1.910 & .130 & - \\
\hline Total & 37.307 & 152 & & & & \\
\hline
\end{tabular}

The results of the analysis indicate a significant difference was not found between the class levels of the mathematics teacher trainees and their metacognitive awareness levels $\left(F_{(3,149)}=1.910, p>.05\right)$. In other words, the metacognitive awareness levels of mathematics teacher trainees do not change significantly according to class levels. However, when the distribution of the metacognitive awareness levels of mathematics teacher trainees according to their class levels (Table 4) is examined carefully, it shows that while the ratio of teacher trainees who have very high level of metacognitive awareness levels was rather high for the first class (\% 29.5), there is a serious drop in the second class $(\%$ 15.6) which increases slightly in the third class $(\% 17.6)$. The fourth class showed a significant increase in the very high level (\%40). The distribution of metacognitive awareness levels of the teacher trainees according to their class levels can be seen in the Table 4. 
Table 4. Distribution of Metacognitive awareness Levels of the Teacher Trainees According to Their Class Levels

\begin{tabular}{|c|c|c|c|c|c|c|c|c|c|c|}
\hline \multirow{3}{*}{$\begin{array}{l}\text { Metacognitive } \\
\text { Awareness }\end{array}$} & \multicolumn{10}{|c|}{ Class Levels } \\
\hline & \multicolumn{2}{|c|}{ Freshmen } & \multicolumn{2}{|c|}{ Sophomores } & \multicolumn{2}{|c|}{ Juniors } & \multicolumn{2}{|c|}{ Seniors } & \multicolumn{2}{|c|}{ Total } \\
\hline & $\mathbf{f}$ & $\%$ & $\mathbf{f}$ & $\%$ & $\mathbf{f}$ & $\%$ & f & $\%$ & $\mathbf{f}$ & $\%$ \\
\hline Very High. & 13 & 29.5 & 7 & 15.6 & 6 & 17.6 & 12 & 40.0 & 38 & 24.8 \\
\hline High & 29 & 66.0 & 36 & 80.0 & 27 & 79.4 & 17 & 56.7 & 109 & 71.2 \\
\hline Low & 2 & 4.5 & 2 & 4.4 & 1 & 3.0 & 1 & 3.3 & 6 & 3.9 \\
\hline Very Low & 0 & 0.0 & 0 & 0.0 & 0 & 0.0 & 0 & 0.0 & 0 & 0.0 \\
\hline Total & 44 & 100 & 45 & 100 & 34 & 100 & 30 & 100 & 153 & 100 \\
\hline
\end{tabular}

Correlation analysis was performed in order to determine whether there was a relationship between the metacognitive awareness levels of 128 mathematics teacher trainees and university grade point averages or not. The results of the analysis has been stated in Table 5.

Table 5. Results of Correlation Analysis in Relation to Metacognitive awareness Levels of Mathematics Teacher Trainees and Their Grade Point Averages

\begin{tabular}{lccc}
\multicolumn{4}{c}{ Mathematics Teacher Trainees and Their Grade Point Averages } \\
\hline & N & Pearson Correlation & p \\
\hline $\begin{array}{l}\text { Metacognitive Awareness Levels } \\
\text { Grade Point Averages }\end{array}$ & 128 & .218 & .014 \\
\hline
\end{tabular}

Results of the analysis show a low level, positive relationship between metacognitive awareness levels of mathematics teacher trainees and their university grade point averages $(r=0.218, p<0.05)$. Said another way, as the grade point averages of trainees' increases so too does the metacognitive awareness levels. The effects of knowledge of cognition and regulation of cognition, the two domains of the MAI, were examined for using correlation analysis. The results can be seen in Table 6 .

Table 6. Results of Correlation Analysis in Relation to Components of Metacognitive awareness Levels of Mathematics Teacher Trainees and Their University Grade Point Average

\begin{tabular}{lcccc} 
& Teacher Trainees and Their University Grade Point Average & P & Pearson Correlation & \multirow{2}{*}{.133} \\
\hline $\begin{array}{l}\text { Knowledge of Cognition } \\
\text { Grade Point Averages }\end{array}$ & 128 & .133 & \multirow{2}{*}{.011} \\
\hline $\begin{array}{l}\text { Regulation of Cognition } \\
\text { Grade Point Averages }\end{array}$ & 128 & .223 & \\
\hline
\end{tabular}

No relationship was found between metacognitive awareness levels of mathematics teacher trainees in the domain of knowledge of cognition and their university grade point averages, however there was a low level, positive relationship between metacognitive awareness levels of mathematics teacher trainees related in the domain of regulation of cognition and their grade point averages $(\mathrm{r}=0.223, \mathrm{p}<0.05)$. As a conclusion, these results show a weak but significant, positive relationship between the metacognitive awareness levels of teacher trainees and their grade point averages. The distribution of grade point averages of teacher trainees according to their metacognitive awareness levels was examined and is included in Table 7.

Table 7. Distribution of University Grade Point Averages of Mathematics Teacher Trainees According to Their Metacognitive awareness Levels

\begin{tabular}{|c|c|c|c|c|c|c|c|c|c|c|}
\hline \multirow{3}{*}{$\begin{array}{l}\text { Metacognitive } \\
\text { Awareness }\end{array}$} & \multicolumn{10}{|c|}{ Grade Point Averages } \\
\hline & \multicolumn{2}{|c|}{ 1.50-1.99 Points } & \multicolumn{2}{|c|}{ 2.00-2.49 Points } & \multicolumn{2}{|c|}{ 2.50-2.99 Points } & \multicolumn{2}{|c|}{ 3.00-3.49 Points } & \multicolumn{2}{|c|}{ 3.50-4.00 Points } \\
\hline & $\mathbf{f}$ & $\%$ & f & $\%$ & $\mathbf{f}$ & $\%$ & $\mathbf{f}$ & $\%$ & $\mathbf{f}$ & $\%$ \\
\hline Very High. & 0 & 0.0 & 3 & 16.7 & 10 & 18.5 & 13 & 31.7 & 4 & 40.0 \\
\hline High & 4 & 80.0 & 15 & 83.3 & 41 & 75.9 & 27 & 65.9 & 6 & 60.0 \\
\hline Low & 1 & 20.0 & 0 & 0.0 & 3 & 5.6 & 1 & 2.4 & 0 & 0.0 \\
\hline Very Low & 0 & 0.0 & 0 & 0.0 & 0 & 0.0 & 0 & 0.0 & 0 & 0.0 \\
\hline Total & 5 & 100 & 18 & 100 & 54 & 100 & 41 & 100 & 10 & 100 \\
\hline
\end{tabular}


The metacognitive awareness levels of $20 \%$ of teacher trainees whose university grade point averages are between 1.50 and 1.99 were low. The metacognitive awareness levels were low for a very small percentage (8\%) the teacher trainees who had higher grade point averages. However, as the grade point averages increased, the percentage rate related to the number of teacher trainees whose metacognitive awareness levels were very high also increased $(0.0 \%-16.7 \%-18.5 \%-31.7 \%)$. As grade point averages increased, the percentage of teacher trainees who have high metacognitive awareness levels decreased and the percentage rate related to the number of teacher trainees who have very high metacognitive awareness levels increased. The percentage rate related to the number of teacher trainees, who have high metacognitive awareness levels are $60 \%$ and over.

\section{DISCUSSION AND CONCLUSION}

The goal of this study was to describe the metacognitive awareness levels of teacher trainees who study in the elementary mathematics teacher education department at a large university in Turkey and to research whether these levels vary significantly according to gender and class levels. We also wanted to examine the relationship between the metacognitive awareness levels and the university grade point averages. For this purpose, the Metacognitive Awareness Inventory (MAI), which was developed by Schraw and Dennison (1994) and was transcribed into Turkish by Akın, Abacı and Çetin, was implemented with 153 teacher trainees.

Analysis of the data found that the majority of the teacher trainees had high level of metacognitive awareness (71.2\%) as compared to the teacher trainees who had very high level of metacognitive awareness (24.8\%), suggesting that for many students the metacognitive awareness level can be increased. On the other hand, it can also be said that the teacher trainees have a high level of metacognitive awareness, in general, since only a minority of teacher trainees have a low level of metacognitive awareness $(4 \%)$. The findings of this research show that the metacognitive awareness levels of the majority of teacher trainees are high but their awareness levels could be develop to have very high level of metacognitive awareness. This is supported by the research of Özsoy and Günindi (2011) with teacher trainees in different fields. These results indicate the need for the awareness of teacher trainees to be developed.

We also found that there is not a significant difference between the metacognitive awareness levels of trainees by either gender or class levels. These results support the results of the research of Özsoy and Günindi (2011) and by Tüysüz, Karakuyu and Bilgin (2008) who had similar findings. At the same time the distribution of the metacognitive awareness levels of teacher trainees according to their class levels was rather high for the first class (\% 29.5), dropped in the second class, started to increase in the third class and rose to a much higher ratio in the fourth class $(40 \%)$. In fact, where the high level of metacognitive awareness of teacher trainees in the third class of the university decrease and the very high level of metacognitive awareness (ones who have metacognitive awareness level scores are between 3.75 and 5.00) gradually rise and are higher during the fourth class as compared to other classes, gives rise to the thought that as the teacher trainees are allowed more interaction during the third and fourth classes and as lessons are more student oriented, that this active participation of students has an effect.

The results of analysis of the relationship between the metacognitive awareness levels of mathematics teacher trainees and their university grade point averages showed there was a low level, positive relationship $(\mathrm{r}=0.218, \mathrm{p}<0.05)$ and that this relationship occurs in the regulation of cognition domain $(\mathrm{r}=0.223, \mathrm{p}<0.05)$. This shows that the metacognitive awareness levels and the average grades related to the regulation of cognition component of the trainees raise as the grade point averages raise. Similar results were obtained by Cardelle-Elawar (1992), Özcan (2000), O'neil and Abedi (1996) and by Swanson (1990). In addition to this; the regulation of cognition component has an effect, even though it is low, on the successes of the lectures of the trainees but the information related to the knowledge of cognition component does not have an effect on the university lecture successes. It can be seen from this the teacher trainees, who have very high levels of metacognitive awareness and who use the information that is related to the knowledge of cognition component, could get higher grade point averages and so be more successful. Because of that, it is possible that metacognitive awareness levels could have even if a bit effect on the general success of trainees.

In the meantime, the fact that as the university grade point averages increase, the percentage rate with regards to the number of the teacher trainees, who have very high level of metacognitive awareness, also increase, 
gives rise to the thought, where the teacher trainees would have higher metacognitive awareness levels as their grade point averages increase. As a result, the findings of this research shows that although most of the mathematics teacher trainees metacognitive awareness level have high level of metacognitive awareness but their awareness could be develop to have very high level of awareness. This result is in accord with the results of research of Özsoy ve Günindi (2011). This situation indicates that the need for mathematics teacher trainees to develop their awareness.

The metacognitive awareness of teachers and their skills affects their individual success in their educational and professional lives and also potentially the success of their students. Having knowledge about metacognitive processes and using these processes in the most effective and the most productive way increases the metacognitive awareness level of the individual (Livingston, 1997; Marshall, 2003). It is an important issue for this reason that teachers and teacher trainees should have high levels of metacognitive awareness and be able to model this awareness for the learning of their students. In order for the teachers to develop their metacognitive awareness and to enhance their knowledge and skills with metacognitive, application examples could be organised by specialists. The help and support they require can be provided through counselling services in this field. Inclusion of activities that develop and support knowledge, skill and awareness of metacognition during lectures that teacher trainees take would be appropriate and could help develop metacognitive awareness.

In conclusion, teachers and teacher trainees can develop themselves by trying to stage their skills in this field during their applications, by comparing these applications with the ideal applications, by analysing and evaluating the differences between them, by changing these to a form that would be more beneficial for their purpose and through appropriate counselling services. In addition to this, since there is the fact that metacognitive awareness levels of the majority of teacher trainees is not developed in full yet, this also shows the need for more detailed research which would put forward what the teachers and teacher trainees know about metacognition and where their shortcomings are. It would be appropriate for this research to determine the shortcomings of the teachers and the teacher trainees about metacognitive awareness and following this to create solutions of how to eliminate these shortcomings. Finally the results need to be shared with the research community.

\section{AUTHOR INFORMATION}

Dr. Dilek Sezgin Memnun joined the faculty at Uludag University in 2001. She studied for the master program of Uludag University Social Sciences Institute in the 2001-2003 years and the doctoral program of Uludag University Education Sciences Institute in the 2006-2011 years. She is working as a research assistant in Uludag University in Bursa since 2002. She is a research scholar at Georgia State University since March 2010. Her primary research interest is Metacognition, Metacognitive Awareness, Constructivism, Realistic Mathematics Education, Active Learning, Probability and Statistics Education, Problem Solving, Learning of Linear Equations. She is published in different academic journals. She is a member in the National Council of Teachers of Mathematics and School Science and Mathematics Association. E-mail: dsmemnun@uludag.edu.tr. Corresponding author.

Dr. Lynn Hart joined the faculty at Georgia State University in 1987. She holds a joint appointment in the Department of Early Childhood Education (ECE) and the Department of Mathematics. She co-directs the Collaborative Master's Program (CMP) in ECE. Her primary research interest is teacher development, teacher change and the role of beliefs in teaching. She is published in the Journal of Mathematics Teacher Education, International Journal of Teacher Development, Journal for Research in Mathematics Education, School Science \& Math, NCTM Yearbooks, Teaching Children Mathematics, The Journal for Excellence in College Teaching, and others. She is a member in the AERA Special Interest Group: Research in Mathematics Education, the International Group for the Psychology of Mathematics Education and the National Council of Teachers of Mathematics. E-mail: lhart@gsu.edu. 


\section{REFERENCES}

1. Akın, A., Abacı, R., \& Çetin, B. (2007). The validity and reliability of the Turkish version of the metacognitive awareness inventory. Educational Sciences: Theory \& Practice, 7(2), 671-678.

2. Artzt, A.F., \& Armour-Thomas, E. (1992). Development of a cognitive-metacognitive framework for protocol analysis of mathematical problem solving in small groups. Cognition and Instruction, 9(2), 137175.

3. Blakey, E., \& Spence, S. (1990). Developing metacognition. Syracuse, NY: ERIC Clearinghouse on Information Resources. [ED327218]

4. Brown, A.L. (1987). Metacognition, executive control, self-regulation, and other more mysterious mechanisms. In F. E. Weinert, R. H. Kluwe (Eds.), Metacognition, motivation, and understanding (pp.65116). Hillsdale, New Jersey: Lawrence Erlbaum Associates.

5. Butler, D., \& Winne, P. (1995). Feedback and self-regulated learning: A theoreical synthesis. Review of Educational Research, 65, 245-281.

6. Cardelle-Elawar, M. (1992). Effects of teaching metacognitive skills to students with low mathematics ability. Teaching and Teacher Education, 8, 109-121.

7. Desoete, A., Roeyers, H., \& Buysee, A. (2001). Metacognition and mathematical problem solving in grade 3. Journal of Learning Disabilities, 34, 435-449.

8. Ekiz, D., \& Yiğit, N. (2007). An investigation of student teachers' views of the teacher education models from the angle of different teacher education programs and genders. Journal of Turkish Educational Sciences (Türk Eğitim Bilimleri Dergisi), 5(3), 543-557.

9. Filho, M.K.D.C., \& Yuzawa, M. (2001). The effect of social influences and general metacognitive knowledge on metamemory judgments. The Journal of Experimental Education, 69(4), 325-343.

10. Fitzpatrick, C. (1994). Adolescent mathematical problem solving: The role of metacognition, strategies and beliefs. Paper presented at the Annual Meeting of the American Educational Research Association, New Orleans, La., April. ERIC Clearinghouse on Information Resources. [ED374969].

11. Flavell, J. (1976). Metacognitive aspects of problem solving. In L. Resnick (Ed.), The Nature of Intelligence. Hillsdale, New Jersey: Lawrence Erlbaum Associates.

12. Flavell, J. (1979). Metacognition and cognitive monitoring. American Psychologist, 34, 906-911.

13. Flavell, J. (1993). Cognitive development. Englewood Cliffs, NJ: Simon \& Schuster.

14. Jacobs, J.E., \& Paris, S.G. (1987). Children's metacognition about reading: Issues in definition, measurement, and instruction. Educational Psychologist, 22, 255-278.

15. Kapa, E. (2001). A metacognitive support during the process of problem solving in a computerized environment. Educational Studies in Mathematics, 47, 317-336.

16. Kramarski, B., Mevarech, Z.R., \& Arami, M. (2002). The effects of metacognitive instruction on solving mathematical authentic tasks. Educational Studies in Mathematics, 49, 225-250.

17. Kuiper, R. (2002). Enhancing metacognition throught the reflective use of self-regulated learning strategies. The Journal of Continuing Education in Nursing, 33(2), 78-87.

18. Lin, X. (2001). Designing metacognitive activities. Educational Technology Research and Development, 49(2), 23-40.

19. Livingston, J.A. (1997). Metacognition: An overview. Retrieved October 21, 2008, from http://www.gse.buffalo.edu/fas/shuell/CEP564/Metacog.htm.

20. Lucangeli, D., \& Cornoldi, C. (1997). Mathematics and metacognition: What is the nature of the relationship? Mathematical Cognition, 3(2), 121-139.

21. Marshall, M. (2003). Matecognition thinking about thinking is essential for learning. Teachers.Net Gazzette, 4(3).

22. Mevarech, Z.R. (1999). Effects of metacognitive training embedded in cooperative settings on mathematical problem solving. The Journal of Educational Research, 92(4), 195-205.

23. Nietfeld, J.L., Cao, L., \& Osborbe, J.W. (2005). Metacognitive monitoring accuracy and student performance in the postsecondary classroom. The Journal of Experimental Education, 74(1), 7-28.

24. O’Neil, H.F., \& Abedi, J. (1996). Reliability and validity of a state metacognitive inventory: Potential for alternative assessment. The Journal of Educational Research, 89, 234-245.

25. Öz, H. (2005). Metacognition in foreign second language learning and teaching. Hacettepe University Journal of Education, 29(2), 147-156. 
26. Özcan, Z.Ç.K. (2000). Teaching metacognitive strategies to $6^{\text {th }}$ grade students. (Unpublished Master Thesis). Boğaziçi University, Istanbul, Turkey.

27. Özsoy, G., \& Günindi, Y. (2011). Prospective preschool teachers' metacognitive awareness. Elementary Education Online, 10(2), 430-440.

28. Pintrich, P.R. (2002). The role of metacognitive knowledge in learning, teaching, and assessing. Theory into Practice, 41(4), 219-225.

29. Schoenfeld, A.H. (1985). Mathematical problem solving. Orlando, FL: Academic Press.

30. Schraw, G. (1998). Promoting general metacognitive awareness. Instructional Science, 26, 113-125.

31. Schraw, G., \& Graham, T. (1997). Helping gifted students develop metacognitive awareness. Roeper Review, 20, 4-8.

32. Schraw, G., \& Moshman, D. (1995). Metacognitive theories. Educational Psychology Review, 7, 351-371.

33. Schraw, G., \& Sperling-Dennison, R. (1994). Assessing metacognitive awareness. Contemporary Educational Psychology, 19, 460-470.

34. Sperling, R.A., Howard, B.C., Staley, R., \& DuBois, N. (2004). Metacognition and self-regulated learning constructs. Educational Research and Evaluation, 10(2), 117-139.

35. Swanson, H.L. (1990). Influence of metacognitive knowledge and aptitude on problem solving. Journal of Educational Psychology, 82(2), 306-314.

36. Teong, S.K. (2002). The effect of metacognitive training on mathematical word-problem solving. Journal of Computer Assisted Learning, 19(1), 46-55.

37. Thomas, G.P., \& McRobbie, C.J. (2001). Using a metaphor for learning to improve students' metacognition in the chemistry classroom. Journal of Research in Science Teaching, 38, 222-259.

38. Tüysüz, C., Karakuyu, Y. \& Bilgin, I. (2008). Öğretmen adaylarının üst biliş düzeylerinin belirlenmesi. (Teacher trainees' metacognitive awareness levels) Abant İzzet Baysal Universitesi Sosyal Bilimler Dergisi (Abant İzet Baysal University Journal of Social Sciences), 17(2), 147-158.

39. Victor, A.M. (2004). The Effects of Metacognitive Instruction on the Planning and Academic Achievement of First Grade and Second Grade Children (Yayınlanmamış Doktora Tezi). Illinois Institute of Technology. Retrieved February 23, 2005 from ProQuest Digital Dissertations.

40. Yurdakul B. (2005). Biliş ötesi ve yapılandırmacı öğrenme çevreleri (Metacognitive and constructivist learning environments). Educational Administration-Theory and Practice, 42, 279-298

41. Williamson, R.A. (1996). Self-questioning: An aid to metacognition. Reading Horizons, 37, 30-47.

42. Zimmerman, B.J. (1989). A social cognitive view of self-regulated academic learning. Journal of Educational Pyschology, 81(3), 329-339.

43. Zimmerman, B.J., \& Martinez-Pons, M. (1988). Construct validation of a strategy model of student selfregulated learning. Journal of Educational Psychology, 80(3), 284-290.

44. Zimmerman, B.J., \& Paulsen, A.S. (1995). Self-monitoring during collegiate studying: An invaluable tool for academic self-regulation. In Pintrich (Ed.), New Directions in College Teaching and Learning: Understanding Self-Regulated Learning. San Francisco, CA: Jossey-Bass. 